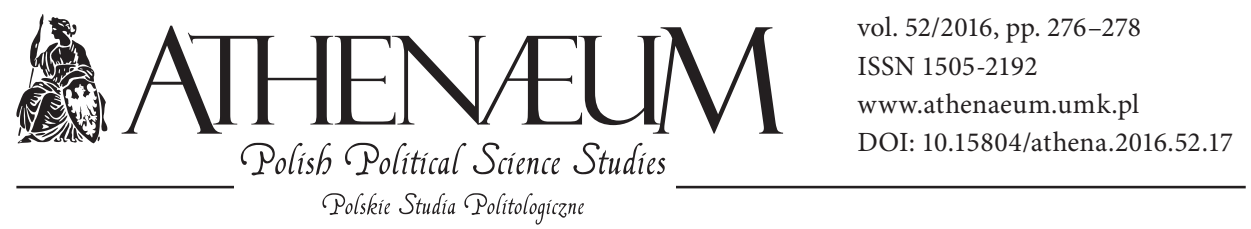

Przemysław Wywiał, Organizacje proobronne w systemie bezpieczeństwa narodowego Polski, Difin, Warszawa 2016, pp. 175

\title{
Patryk Tomaszewski*
}

In the recent years, there is a steady increase in the interest in pro-defensive organizations in our country. There are a few reasons for that.

- Since 2008, we have been witnessing rapidly changing foreign policy exercised by the Russian Federation towards its neighboring countries. What is mainly meant by that is the war against Georgia - regardless of the mistakes committed by the authorities in Tbilisi, the mistakes still giving pretext to Russian intervention. Next, what we witness is the annexation of Crimea by Russia or the outburst of the hybrid war in the eastern Ukraine.

- The debate on the change in Polish Military Power - reorganizing National Reserve Forces and founding Territorial Defense Forces.

- The increasingly imminent threat of terrorist attacks in Western Europe.

* Nicolaus Copernicus University, Faculty of Political Sciences and International Studies.
- A certain trendy inclination towards patriotism as well as combat and shooting sports among nowadays youth.

In the present year, there have been two books published dedicated to pro-defensive organizations. One of them is of journalistic nature - Militarni. Już wojskowi czy jeszcze cywile. Polskie organizacje proobronne [The Military Ones: Between Army Men and Civilians. Polish Pro-defensive Organizations] - was written by journalists Wojciech Chełchowski and Andrzej Czuba. The other one - being the one reviewed here - is the monograph written by the scholar of Instytut Bezpieczeństwa i Edukacji Obywatelskiej Uniwersytetu Pedagogicznego w Krakowie [the Institute of Safety and Citizenship Education of the Pedagogical University of Cracow], dr. Przemysław Wywiał.

The monograph by Wywiał is not the first publication raising the issues pertaining to pro-defensive organizations. Much earlier, in 2006, there was an extensive work 
by prof. Aleksandra Skrabacz on NGOs, the work bearing a title Organizacje pozarzadowe w Bezpieczeństwie Narodowym Polski [Non-government Organizations in the National Security of Poland].

Just to commence the debate on pro-defensive organizations, one should raise the question of which non-governmental organizations should be subsumed under the category of pro-defensive ones? Obviously, the ones regarded as pre-defensive ones are granted the larger scope for operations and thus they might enter such realms as education or life-saving. On the other hand, paramilitary organizations will be organized in a sheer military manner although they do not constitute the army as such (Wywiał, p. 63).

Typologies of pro-defensive organizations can be many. For instance, they can be divided using the criterion of the purpose (educational-pedagogical organizations, the ones specialized in the Common Safety sector, veteran, reservist, the ones spreading the problems of defense, and finally - paramilitary ones).

In his book, Przemysław Wywiał attempts to present the said issues possibly extensively. The monograph poses problems which it attempts to solve. In the successive chapters, the author presents to the reader such issues as the characteristics of civil society. What is also included is the historical sketch of pro-defensive organizations ranging from World War I up to 1989 . In the next, third chapter, the author raises the problem of the functioning of pro-defensive organizations in selected democratic countries (Sweden, Estonia, Lithuania, Finland). He points out that these units are considerably endorsed by the states and they fall into not only the defensive system but also into the extra-military one, that is anti-crisis one. In the next chapter, dr. Wywiał depicts particular organizations operating in Poland. It is a cross-sectional collection, however selective. The author's selection is based on the official information on particular organizations. It is regrettable that he does not conduct any qualitative research - at least in the form of leading activists of respective organizations. He also skips quite a large number of strictly training and paramilitary organizations, such as, say, Fundacja "Szturman" [The "Szturman" Foundation], Polski Związek Instruktorów i Trenerów Formacji Ochronnych [The Polish Association of Security Units Instructors and Trainers], or Fundacja Byłych Żołnierzy Jednostek Specjalnych GROM [The Former Special Forces Soldiers of GROM Foundation].

The next chapter, the fifth one, is related to a really significant issue which is the cooperation of the said units with the army. From this chapter the reader can learn what are the nowadays legal regulations and how to sign up for the cooperation with MON [Ministry of National Defence]. The author also presents the selected samples of specific contracts.

Chapter six raises the issue of the Federation of Pro-defensive Organizations. The idea of more efficient use of the poten- 
tial of associations of this sort emerged in the Ministry of National Defence in 2014. Who was appointed then was the spokesman of the Ministry of National Defence for the Social Pro-defensive Initiatives, and the one granted this function was general Bogusław Pacek. The initiative was met with considerable approval from the part of non-governmental organizations; however, despite the far-reaching plans of cooperation and consolidation of the organizations, the more extended operations of the Federation failed to materialize. So, the author of the monograph rightly concludes: "Unfortunately, it seems that the Federation, as it is shaped these days, neither meets the expectations of the defensive associations, and nor will it contribute to building the system of the territorial defense in Poland, which was originally the subject of great expectations" (p. 121). Eventually, after the change in the administrative board of MON, the new concept of forming the brigades of Territorial Defense was put into practice, the building of which many pro-defensive organizations were involved in.

The next chapter of the book describes the operations conducted by one of the most active organizations for Territorial Defense. What is meant here is Stowarzyszenie Obrona Narodowa.pl - Ruch na
Rzecz Obrony Terytorialnej [The Movement for Territorial Defense].

The last chapter is devoted to the role of veteran organizations in promoting patriotism.

The book by Przemysław Wywiał is of the nature of the synthetic review of the problem. Unfortunately, what it provides is the descriptive overview of the organizations operating in the broadly construed realm of defense. However, it does not answer the question what role, in fact, these organizations are supposed to play. Are they to be considered, as General Pacek originally assumed, rather as a reserve unit for the army or, alternatively, some support for the actions during peacetime, for example, supporting emergency management. Or should it be a component of Territorial Defense, and thus, in fact, a part of military forces? The book lacks interviews with the activists of pro-defensive organizations, or politicians and scholars dealing with said problems. In conclusion, one might say that the book concerns the most important aspects of the functioning of contemporary pro-defensive organizations. Regrettably, it does not provide any answer as to in which direction these organizations should be heading and what is their place in the system of national defense in the currently changing international environment. 